\title{
THE CONCEPT OF PROPER QUALITY OF CONSTRUCTION WORKS IN LITHUANIAN CONSTRUCTION LAW
}

\author{
Sigitas Mitkus \\ Department of Business Management, Vilnius Gediminas Technical University, \\ Sauletekio al. 11, LT-10223 Vilnius, Lithuania \\ E-mail: sigitas.mitkus@vgtu.lt
}

\begin{abstract}
The article analyses the concept of proper quality of construction works in law of the Republic of Lithuania. The analysis covers the quality requirements laid down in the Law on Construction, the Civil Code and case law. The article also defines and analyses the main categories used in Lithuanian law to characterise the quality of construction works, in particular, compliance with the standard quality of a construction works, compliance with the quality requirements set in contract documents, compliance with the requirements ordinarily presented for work of the respective nature, and fitness for use in accordance with its designation within the limits of a reasonable period.
\end{abstract}

Keywords: construction law, quality of construction works, case law, construction works, proper quality; construction management.

JEL Classification: K12; L74; L15.

\section{Introduction}

Quality definitely is one of most essential properties of construction works. Ooi et al. (2014) found strong evidence that selling price of new houses and appreciation rate are related significantly to construction quality.

Evaluation of the quality of construction works often have multicriteria nature.

Multicriteria methods were applied in Lithuania for the first time more than 30 years ago to solve technological problems in construction (Ginevičius et al. 2013). Multicriteria evaluation methods began to be applied in Lithuania in construction. Many multicriteria quality assessment methodologies are developed. Kutut et al. (2013) created multi-criteria assessment methodology for buildings located in the historic city centre of Vilnius, Zavadskas et al. (2013) - for facades' alternatives, Medineckiene et al. (2015) - for sustainable building assessment/certification, Kaklauskas et al. (2006) - for windows, Kalibatas et al. (2011) - for indoor environment of dwelling-houses, Zagorskas et al. (2014) - thermal insolation alternatives of historic brick buildings, Staniūnas et al. (2013) for multi-dweling house modenization.

In many cases, the quality has to be seen in conjunction with other characteristics of the construction works, construction process etc. Advanced multicriteria models can promote quality and reputation in construction (Costa, Tavares
2013). Tamošaitienè et al. (2013) analysed multicriteria risk assessment of a construction project. Quality is one of key evaluation criteria assessing sustainability of buildings (Drejeris, Kavolynas 2014), projects' performans in construction (Tamošaitienè et al. 2013).

The planning phase of every construction project is entangled with multiple and occasionally conflicting criteria which need to be optimized simultaneously, and one key criteria is quality of construction works. Monghasemi et al. (2015) for the first time applied an evidential reasoning (ER) approach in the context of project scheduling to identify the best Pareto solution for discrete timecost-quality. By investigating the performance of each scheduling alternative based on multiple criteria (e.g., time, cost, and quality), the proposed approach proved effective in raising the efficiently of construction project scheduling.

Quality control techniques and process are of particular importance to the quality assurance. Numerous publications are published on the issue. Random third party quality audits are mandatory by the regulations for public construction projects in Taiwan. Wang and Kong (2012) created a genetic algorithm-based model to assist with the project selection and auditor assignment. Ko and Li (2014) analyzed construction inspection methods in public projects. Wu et al. (2012) described quality selfcontrol and co-supervision mechanism of construction agent in public investment project in China. 
In order to give more computerized support to the construction quality compliance Zhong et al. (2012) explored an ontology-based semantic modeling approach of regulation constraints checking against regulations. Quality control issues also dealt with Taylor et al. (2013), Heras-Saizarbitoria et al. (2013).

Construction by BIM (building information modeling) methodology can significantly improve the quality of construction works (Eadie et al. 2013; Choi et al. 2014; Porwal, Hewage 2013; Bryde et al. 2013; Succar et al. 2013). Facility management services also have significant influence to quality of buildings (Lepkova, Uselis 2013; Ancarani, Capaldo 2005). Clear quality requirements reduce conflicts between participants of the construction (Mitkus, S., Mitkus, T. 2014a, 2014b; Ceric 2014).

Regulations play an important role in assuring the construction quality (Zhong et al. 2012). McGibbney and Kumar (2013) analyzed Scottish building regulations, which govern 32 local authorities across the country and created on the ground methodology and subsequent production of an intelligent XML authoring workflow model (DROID-SL) for such documents which displays how legal texts of this nature can be better consumed within society. Ab-Sani and Othman (2012) reviewed the status of soft-scape construction quality standards and specification in Malaysia.

A contractor is required to fulfil construction operations of proper quality. The term proper quality is used in the Civil Code of the Republic of Lithuania (LRS 2000) and case law. Proper (improper) quality and fulfilment of work are referred to in many articles of the Civil Code of the Republic of Lithuania (LRS 2000). Article 6.658(3) of the Civil Code of the Republic of Lithuania (LRS 2000) stipulates: "If during the fulfilment of work it becomes evident that it will not be properly performed [...]", Article 6.659(1) reads: "poor or improper quality of the materials, other property or documents received from the customer", "consequences threatening the appropriateness or stability of the work due to the compliance with the instructions of the customer concerning the methods of the fulfilment of work", "other circumstances beyond the control of the contractor which threaten the appropriateness, stability or security of the work".

The term proper quality is also widely used by the Supreme Court of Lithuania. The court has stated: "The contractor shall be deemed to have properly performed his obligations under the construction contract, if the fulfilled work (result) is of proper quality" (Supreme Court of Lithuania 2014), "contractor shall be deemed duly fulfilled the obligation under the construction contract, if the work carried out (result) is of proper quality" (Supreme Court of Lithuania 2013), "the contractor is obliged to fulfil work of proper quality from his own materials or materials provided by the customer in accordance with the conditions determined by the customer and within the established period of time" (Supreme Court of Lithuania 2010a), etc.

The purpose of the article is to identify what constitutes the proper quality of construction works in Lithuanian construction law.

\section{Standard quality of a construction works}

Article 2(40) of the Law on Construction (LRS 1996) provides the following definition of the standard quality of a construction works:

40. Standard quality of a construction works means the quality of the design documentation of a construction works, construction operations and the constructed construction works which meets the requirements set out by normative technical construction documents and normative construction works safety and designation. documents.

The definition above implies that a construction works shall be deemed to be in compliance with the standard quality of a construction works if its design solutions, construction operations wherefrom it results and the construction works itself meet the requirements laid down in normative technical construction documents and normative construction works safety and designation documents (see Fig. 1).

It should be noted that other provisions of the Law on Construction (LRS 1996) also set forth that a construction works must meet namely the standard quality of a construction works: Articles 2(50) and 2(51) stipulate that the construction manager and the technical supervisor of the construction, respectively, shall be responsible for the standard quality of the construction works.

The Law on Construction (LRS 1996) further provides definitions of normative technical construction documents and normative construction works safety and designation documents. A normative technical construction document is defined in Article 2(54) of the Law on Construction (LRS 1996):

Normative technical construction document means a document which sets out requirements, rules, general principles and characteristics pertaining to design, construction, construction com- 
pletion, use, maintenance and demolition of a construction works. It shall comprise technical construction regulations, the construction code, directions for the use and maintenance of construction works, standards, technical approvals, methodological instructions, and recommendations.

This definition does not provide a clear explanation of a normative technical construction document. The first sentence lists construction stages regulated by normative technical construction documents (design, construction, construction completion, use, maintenance and demolition of a construction works). The second sentence indicates the types of normative technical construction documents (technical construction regulations, the construction code, directions for the use and maintenance of construction works, standards, technical approvals, methodological instructions, and recommendations).

Both sentences of the definition give rise to some uncertainties. Firstly, it is not clear whether legal sources regulating other construction-related areas that are not mentioned in the legal provision at issue fall within the term of normative technical construction documents or not. For example, those regulating the types of construction works, attestation procedures applicable to entities involved in construction, etc. Secondly, it is not clear whether legal sources that do not fall within the category of the legal sources listed in the second sentence of the definition are to be considered normative technical construction documents. For example, it is not clear whether hygiene standards establishing requirements for buildings, legal acts of local authorities regulating construction procedures, etc. are to be considered normative technical construction documents in accordance with the given definition.

The system of normative technical construction documents is described in Article 8 of the Law on Construction (LRS 1996). This article extends the definition of a normative technical construction document. It sets forth that normative technical construction documents shall be as follows:

1) technical construction regulations;

2) rules for construction and maintenance of construction works;

3) Lithuanian standards prepared and adopted in the manner prescribed by the recognised national standardisation institution;

4) technical approvals;

5) methodological instructions, recommendations;

6) The essential requirements (one, several or all) of construction works specified in Regulation (EU) No. 305/2011.
Therefore, Article 8 of the Law on Construction (LRS 1996) appears to have greatly extended the concept of a normative technical construction document. However, not all uncertainties have been eliminated. It is still unclear whether legal acts adopted by the bodies other than institutions authorised by the Government (institutions of the Parlament, Government, local authorities) are to be qualified as normative technical construction documents. Similarly, it remains unclear whether legal acts adopted by the institutions authorised by the Government should be considered normative technical construction documents if the lay down requirements other than the essential requirements for construction works.

To sum up, it can be concluded that the definition of a normative technical construction document provided in the Law on Construction (LRS 1996) is not completely clear. It would be much clearer to apply the term legal source, as used in the theory of law and other branches of law, whereas the term normative technical construction document should be abandoned at all.

Construction operations require compliance with of all valid legislation regulating the construction process irrespective of legal sources they are contained in, whether or not they are qualified as normative technical construction documents.

Accordingly, the concept of normative technical construction documents carries only a theoretical meaning in practice and the analysed inaccuracies of the definition are not important in practice. In some cases, however, the concept may become a source of misunderstandings and thus should be abandoned or revised.

In addition to normative technical construction documents, the Law on Construction (LRS 1996) also contains a definition normative construction works safety and purpose documents which is presented in Article 2(55) of this law.

The issue of those regulatory documents is delegated under the Law on Construction (LRS 1996) to institutions of the state supervision of safety and designation requirements for a construction works, i.e. to state institutions which enjoy management powers and carry out the activities within a certain field, established by laws and Government resolutions, or exercise state supervision of construction operations related to safety and designation requirements for a construction works (Article 2(55) of the Law on Construction (LRS 1996)).

The areas regulated by normative construction works safety and designation documents have been distributed among state institutions by the Resolu- 
tion No. 1316, October $21^{\text {st }}, 2004$, of the Government of the Republic of Lithuania on the approval of the Distribution of Regulation Areas of Normative Documents of Building safety and Purpose Between Public Authorities (2004). The Government has delegated this regulatory function to 23 state institutions, of which the Ministry of the Environment has been delegated the biggest number of regulation areas.

Pursuant to Article 8 of the Law on Construction (LRS 1996), normative construction works safety and designation documents shall apply on a mandatory or voluntary basis ( $\S 2$ and 3 ). This classification is transposed in paragraph 12 of Technical Construction Regulation STR 1.01.05:2007 "Normative Technical Construction Documents". The mandatory normative technical construction documents include technical construction regulations and legal acts of the institutions authorised by the Government, laying down the essential requirements for construction works and the technical parameters of the construction works pursuant to the levels and classes of the characteristics of construction works or construction products. These documents shall be mandatory to all participants of construction, as well as to public administration entities, owners (users) of engineering networks and transport communications, legal and natural persons the activities whereof are regulated by the Law on Construction (LRS 1996).

The normative technical construction documents applied on a voluntary basis include the construction code, directions for the use and maintenance of construction works, Lithuanian standards and technical approvals, except for the cases when technical construction regulations or other legal acts indicate that it is obligatory to apply the said rules, standards, approvals. The construction code, Lithuanian standards and technical approvals to which reference is made in design contracts or construction works contracts shall be binding to the parties thereto.

\section{Quality requirements set forth in the Civil Code}

The Law on Construction (LRS 1996) uses the definition of the standard quality of a construction works in the narrow sense. Taking into account that quality parameters of many construction works are not regulated by normative technical construction documents and normative construction works safety and designation documents, this concept of quality is defined very vaguely. The Law on Construction (LRS 1996) does not even mention that the quality of a construction works must meet the requirements set in contracts of construction works.

The aforementioned gaps are filled with provisions of the Civil Code of the Republic of Lithuania (LRS 2000). Article 6.663 of the Civil Code of the Republic of Lithuania (LRS 2000) stipulates that the quality of the work fulfilled by the contractor must conform to the conditions of the construction contract. Article 6.684(1) reads that the contractor shall be obliged to perform the construction work in accordance with the requirements established in the technical construction regulations and the contract (contractual documentation). Article 6.684(1) further reads that quality requirements must be stipulated in the contract. Article 6.684(2) defines technical construction regulations as documents indicated in the contract and related thereto (it should be noted that this definition is not identical with the definition of normative technical construction documents in the Law on Construction (LRS 1996)). In simplistic words, normative construction documents (being related to the contract) may be deemed to constitute a part of the contract and, hence, not identified as a separate group of quality requirements.

It should be noted that a design of a construction works is also a part of the contract (contractual document) which defines the object of the contract, i.e. the result that must be transferred by the contractor to the customer. Therefore, it may be concluded that quality requirements of the contract are inclusive of the quality requirements set in the design of the construction works.

Unfortunately, there are frequent instances in practice when quality requirements for the result of construction operations are laid down neither in contracts of construction works nor in normative documents. In such cases, the provision in Article 6.663(1) of the Civil Code of the Republic of Lithuania (LRS 2000) should apply: in the absence of any determination of quality in the contract, the quality of the work fulfilled (result) must conform to the requirements ordinarily presented for work of the respective nature and the result of the work fulfilled must be fit for use in accordance with its designation within the limits of a reasonable period of time.

To sum, up, it may be concluded that the Civil Code of the Republic of Lithuania (LRS 2000) sets out the following quality requirements for construction operations:

- construction operations must conform to the requirements laid down in the contract; 
- construction operations must conform to the requirements ordinarily presented for work of the respective nature;

- the result of the work fulfilled must be fit for use in accordance with its designation within the limits of a reasonable period of time.

A review of all those requirements is provided below.

\section{Contractual requirements for the quality of construction works}

The Civil Code of the Republic of Lithuania (LRS 2000) establishes the principle of freedom of contracts. The conditions of a contract shall be established by the parties at their own discretion, except in the cases where certain conditions of a contract are determined by the mandatory rules of law (Article 6.155 of the Civil Code of the Republic of Lithuania (LRS 2000)).

The parties to a contract of construction works are free to amend the quality requirements laid down in mandatory normative technical construction documents by raising or lowering them. However, the quality requirements shall not be lowered below the level which is in violation of the basic requirements for construction works laid down in the Regulation (EU) No. 305/2011.

The Civil Code of the Republic of Lithuania (LRS 2000) does not require that a contract of construction works be made in a written form (except for the cases when it is required to prepare a design of a construction works and the design part of the contract must be made in writing). Accordingly, contractual quality requirements may be agreed orally, in writing, or by actions. In addition, the principle of freedom of contracts allows the parties to a contract not only to set quality requirements at their discretion, but also to revise them in the process of contract performance.

A serious problem may arise if quality requirements are not clearly agreed by the parties. In such cases the rules of the interpretation of contracts laid down in Article 6.193 of the Civil Code of the Republic of Lithuania (LRS 2000) shall apply: contracts must be interpreted in accordance with good faith, systematically, etc.

However, unclearly formulated contractual conditions in relation to quality requirements for construction operations, as a rule, inevitably lead to conflicting situations, including judicial disputes. There are many disputes in case law originating from unclearly formulated provisions of construction works contracts.
On 23 October 2008, a contract of construction works was made between contractor UAB "AR10" and customer UAB "Vaivorykštė" (Supreme Court of Lithuania 2011b). In accordance with paragraph 2.1 of the contract, the contractor has undertaken to perform lowering of high spots down to the altitude of 103.50 in a land plot and outside the land plot; to raise the level of the land plot by $1 \mathrm{~m}$ using sandy soil, including delivery of sandy soil, land levelling, compression, removal of concrete debris, compression and levelling with a bulldozer.

A dispute in this case originated in relation to the contractual quality of works. According to the customer, the contractor should have used so much sand that the land level (height) be one metre up. According to the contractor, it was agreed in the contract to pour one metre of sand on the land without taking into account likely compaction of the soil under the sand.

To resolve the dispute, the Supreme Court of Lithuania expressed its position on contract interpretation issues. The court stated that in accordance with Article 6.193 of the Civil Code of the Republic of Lithuania (LRS 2000), in interpreting a contract, it is first of all necessary to seek for the real intentions of the parties without being limited by the literal meaning of the words. In the event where the real intentions of the parties cannot be established, the contract must be interpreted in accordance with the meaning that could be attributed in the same circumstances by reasonable persons in the corresponding position as the parties (Article 6.193(1)). All conditions of a contract shall be interpreted taking into account their interrelation, the nature and purpose of the contract, and the circumstances under which it was formed. In interpreting a contract, regard must also be taken of the ordinary conditions, irrespective of their expression in the contract. In the event of doubt over notions which may have several meanings, these notions must be understood in the sense most suitable to the nature, essence and subject-matter of the contract. In the event of doubt over conditions of a contract, they shall be interpreted against the contracting party that has suggested thereof, and in favour of the party that accepted those conditions. In interpreting a contract, regard must also be taken of the preliminary negotiations between the parties, practices which the parties have established between themselves, the conduct of the parties subsequent to the conclusion of the contract, and the existing usages.

The court has stated in this case that there are clearly expressed intentions of the parties to the 
contract to lower high spots of the land plot down to the altitude of 103.50 prior to starting land raising by $1 \mathrm{~m}$. Likewise, the contract clearly shows the intentions of the parties in relation to the volume and content of the land raising works. The Supreme Court of Lithuania has further stated that the analysis of all the established circumstances gives grounds to conclude that both the intentions of the parties to the contract upon entering into the contract and the contractual provisions thereof linked the result of contractor's works namely with the raising of the land level by $1 \mathrm{~m}$ using sandy soil rather than with achieving a certain level of altitude. Otherwise, it would be difficult to achieve and/or fix a certain land level in the plot, taking into account likely sedimentation of unstable layer (peat).

Practice shows that similar situations involving different interpretation of the terms and conditions of construction works contracts by the parties are frequent causes of conflicts (Mitkus, S., Mitkus, T. 2014b); vaguely formulated contractual provisions lead to numerous litigations.

Some rules of interpreting a design of a construction works are also laid down in Technical Construction Regulation STR 1.05.06:2010 "Design of a Construction Works" Paragraph 30 of the Regulation sets out conflict resolution rules that should apply if different solution documents contain ambiguous quality requirements:

30. In case of any inconsistencies or discrepancies in Design Documentation, the order of precedence of the documents shall be as follows:

30.1. technical specifications;

30.2. explanatory notes;

30.3. drawings;

30.4. statements of input quantities.

However, the aforementioned provisions of the regulation should apply having in mind that they do not deny the fundamental principles of interpretation of contracts laid down in the Civil Code of the Republic of Lithuania (LRS 2000) and developed in case law. Let's analyse one example. During the process of construction the parties agreed to amend the quality requirements stipulated in the design of the construction works. This agreement was formalised by making amendments in the design drawings. However, other documents of design solutions were not amended, i.e. the quality requirements remained unchanged in technical specifications and explanatory notes.

Formally, in compliance with the provisions of paragraph 30 of STR 1.05.06:2010, the original quality requirements (not amended) should apply by reason that technical specifications and explanatory notes have precedence over drawing solutions.
In the case at issue, however, it is obvious that the parties have agreed to amend the quality requirement and, therefore, the amended quality requirements in the drawings should prevail. It should be noted that such instances are quite common in practice.

The parties to a construction works contract may agree on the construction result of a lower quality as compared to the quality set forth in normative technical construction documents. This is referred to in the Civil Code of the Republic of Lithuania (LRS 2000) as minor deviations from technical construction regulations. Article 6.695(3) of the Civil Code of the Republic of Lithuania (LRS 2000) reads that a contractor shall not be liable for minor deviations from technical construction regulations made with the consent of the customer if he proves that these deviations have not influenced the quality of the construction object and will not bring about negative consequence. As the above mentioned provision of the Civil Code of the Republic of Lithuania (LRS 2000) mentions the consent of the customer, such deviations may be considered to be contractual ones, i.e. the contractor and the customer agree about quality deviations.

The provision above implies certain contradictions. As a rule, deviations from normative technical construction documents (technical construction regulations) have influence on the quality of construction operations and, usually, these deviations bring negative consequences, i.e. poorer quality of the construction result (object). Therefore, this provision of the Civil Code of the Republic of Lithuania (LRS 2000) should be interpreted extendedly rather than literally. The author proposes to interpret this provision in the following manner. The contractor may, subject to the customer's consent, deviate from the quality requirements (not only those laid down in the technical construction regulations, as is provided for in the Civil Code of the Republic of Lithuania (LRS 2000)) if the quality deviations are so insignificant that the customer will able to use the construction result without any tangible inconveniences, the constructed structure will be in conformity to the essential requirements for a construction works, and there will be no violation of public interest.

Moreover, the above quoted provision of the Civil Code of the Republic of Lithuania (LRS 2000) may be interpreted basing on the customer's right to order the result of construction operations that would be of a lower quality than the standard quality. In this case, this provision could be interpreted invoking the general civil law principle of reasonableness. It is not reasonable to prohibit the 
customer from requesting insignificantly lower quality of works from the contractor when this does not infringe the public interest. For example, it would be unreasonable to ban the customer from requesting the contractor to apply, in order to save funds, used construction products, deviate from ordinarily applied aesthetic requirements for finishing works in cellars or other ancillary rooms of little use, in relation whereto aesthetic requirements are not high, etc.

\section{Ordinarily presented requirements}

The question of whether the fulfilled work (result) meets the ordinarily presented requirements often raises disputes between the parties to construction contracts. Due to the lack of special knowledge, courts are also often unable to determine the ordinarily presented requirements. In such cases, persons having special knowledge, i.e. construction expert witnesses, are often consulted. An expert witness means a person with specialist knowledge who produces expert opinions to the court but do not take any decision in the case (Mitkus, S., Mitkus, T. 2014a).

In the general practice of forensic expertise, expert witnesses usually determine the requirements ordinarily raised for construction operations on the basis of methodological and scientific literature, recommendations of construction product manufacturers and requirements for analogue works, as well as their professional experience.

Methodological literature can be naturally considered a source of ordinarily presented requirements as construction professionals are trained namely on the basis of methodological literature. It is unreasonable to believe that builders should perform works of a higher quality than that they have been trained in education institutions for builders. The ordinarily presented requirements may be also determined basing on research results (scientific literature).

Recommendations of construction product manufacturers are an important source for determining the ordinarily presented requirements. Manufacturers' recommendations often contain quality requirements for construction operations performed using their construction products. It is obvious that, unless separately agreed, there are no reasonable grounds for the customer to believe that the contractor performs works of a higher quality than it is recommended by the manufacturer of the relevant construction products.

In the absence of quality requirements for particular construction products in methodological and/or scientific literature and recommendation of construction product manufacturers, the ordinarily presented requirements may be determined on the basis of requirements raised for analogue construction operations.

In practice, there are cases when quality requirements for the result of construction operations are not specified in any of the above-mentioned sources. In such cases, the only way to determine the ordinarily presented requirements is an independent opinion of expert witness. Usually, construction expert witnesses determine the ordinarily raised quality requirements basing on their special knowledge in construction engineering and professional experience.

In addition, when the ordinarily raised quality requirements are determined on the basis of expertise, it is necessary to take into account that it is usually required that the quality of the result of construction works not render the construction works unfit for its designated use. For example, a certain finishing element should be of such a quality that not to stand out from the rest of the finishing and thus, in case of ordinary use of construction works, not to spoil the general view of the construction works or any part thereof.

In Lithuanian legislation, quality requirements are regulated in respect of a small number of construction operations. Therefore, the criterion of ordinarily presented quality requirements is frequently used, including in case law, to determine the quality of construction operations. The Supreme Court of Lithuania has stated: "the duty to perform high quality works means that the works should be in compliance with the terms and conditions of the contract or, where the quality conditions are not regulated by the contract, with ordinarily requirements presented for work of the respective nature, or, in case of a contract of construction works, with the requirements laid down in normative construction documents" (Supreme Court of Lithuania 2005). The need to evaluate whether the quality of works is compliant with the requirements ordinarily presented for work of the respective nature has been mentioned by the $\mathrm{Su}$ preme Court of Lithuania in other cases, too (Supreme Court of Lithuania 2010b, 2010c, 2011a, 2012).

\section{Fitness for use in accordance with the designation within the limits of a reasonable period of time}

As it was stated above, the construction result of proper quality must be also fit for use in accord- 
ance with its designation within the limits of a reasonable period of time. Criteria to determine the reasonable period of time of fitness for use are not clearly defined. In fact, this period should be determined in each case subject to the nature of works, type of the construction products used, type of the construction works, etc.

Article 6.697(1) of the Civil Code of the Republic of Lithuania (LRS 2000) stipulates that a contractor, unless otherwise provided for in the contract of construction work, shall ensure throughout the whole warranty period the compliance of the object of construction to the indicators established in the technical construction regulations and its fitness for the designated use specified in the contract. Article 6.697(2) sets forth that the parties to the contract have the right to agree on a more extended warranty period only. Having regard to these provisions, it would not be logical to consider a reasonable period of fitness for use to be a period longer than the warranty period.

The warranty periods set out in Article 6.698 of the Civil Code of the Republic of Lithuania (LRS 2000) are as follow:

1) five years, as a general rule;

2) ten years, in existence of hidden defects of the elements of a construction works (structures, pipelines, etc.);

3) twenty years, in existence of intentionally hidden defects.

It should be noted that the contractor, designer and technical supervisor of the construction shall not be liable for the defects discovered within the warranty period if it is proved that the defects occurred as a consequence of:
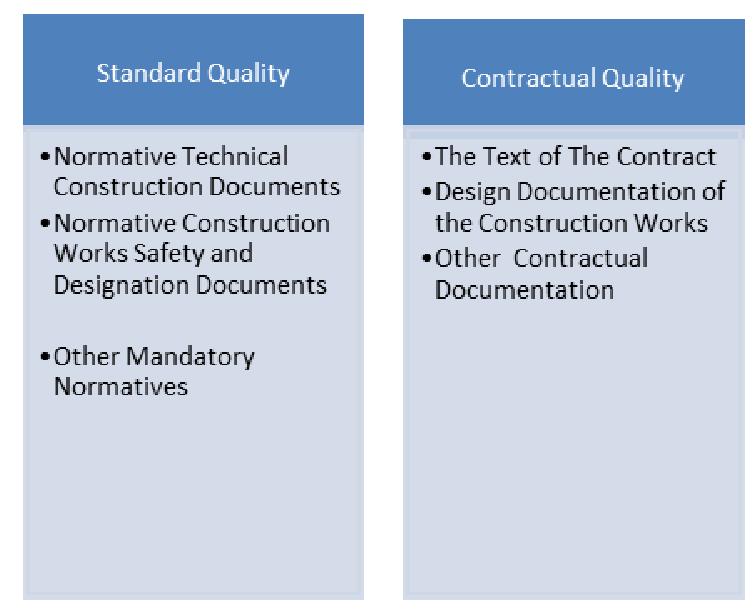

- the normal wear and tear of the objects or parts thereof;

- inappropriate use of the object;

- improper repair made by the customer or third persons engaged by him;

- any other faulty actions of the customer or third persons engaged by him.

As it was mentioned above, a construction works must meet the essential requirements for construction works for an economically reasonable working life. Economically reasonable working life of a construction works is defined in Article 2(70) of the Law on Construction (LRS 1996). The economically reasonable working life of a construction works is further specified in Technical Construction Regulation STR 1.12.06:2002 "The Purpose and Life Span of Construction Works".

\section{Conclusions}

In summary, it can be concluded that the result of construction operations shall be of proper quality if it is:

- in compliance with the standard quality of a construction works;

- in compliance with the quality requirements set in contract documents;

- in compliance with the requirements ordinarily presented for work of the respective nature;

- fit for use in accordance with its designation within the limits of a reasonable period.

Summarized results of the research are presented in Figure 1.

Requirements Ordinarily
Presented for Work of the
Respective Nature
- Methodological
Literature
- Scientific Literature
- Recommendations of
Construction Product
Manufacturers
- Requirements Raised for
Analogue Construction
Operations
-independent
Construction Expert
Opinion

- The Economically

Reasonable Working Life

of a Construction Works

-Warranty Periods

- Cases of Shortening of

Warranty period:

- Normal Wear of

Construction Works;

- Inappropriate Use of

Construction Works

(including repair etc.).

Fig. 1. Proper quality of construction works (Source: compiled by author) 


\section{References}

Ab-Sani, J.; Othman, N. 2012. Quality Standard and Specification for Soft - scape Construction in Malaysia, Procedia-Social and Behavioral Sciences 35: 260-266.

http://dx.doi.org/10.1016/j.sbspro.2012.02.087

Ancarani, A.; Capaldo, G. 2005. Supporting decisionmaking process in facilities management services procurement: A methodological approach, Journal of Purchasing and Supply Management 11(5): 232241. http://dx.doi.org/10.1016/j.pursup.2005.12.004

Bryde, D.; Broquetas, M.; Volm, J. M. 2013. The project benefits of building information modelling (BIM), International Journal of Project Management 31(7): 971-980.

http://dx.doi.org/10.1016/j.ijproman.2012.12.001

Ceric, A. 2014. Strategies for minimizing information asymmetries in construction projects: project managers' perceptions, Journal of Business Economics and Management 15(3): 424-440.

http://dx.doi.org/10.3846/16111699.2012.720601

Choi, J.; Choi, J.; Kim, I. 2014. Development of BIMbased evacuation regulation checking system for high-rise and complex buildings, Automation in Construction 46: 38-49. http://dx.doi.org/10.1016/j.autcon.2013.12.005

Costa, A. A.; Tavares, L. V. 2013. Advanced multicriteria models to promote quality and reputation in public construction e-marketplaces, Automation in Construction 30: 205-215.

http://dx.doi.org/10.1016/j.autcon.2012.11.029

Drejeris, R.; Kavolynas, A. 2014. Multi-criteria evaluation of building sustainability behavior, ProcediaSocial and Behavioral Sciences 110: 502-511. http://dx.doi.org/10.1016/j.sbspro.2013.12.894

Eadie, R.; Browne, M.; Odeyinka, H.; McKeown, C.; McNiff, S. 2013. BIM implementation throughout the UK construction project lifecycle: an analysis, Automation in Construction 36: 145-151. http://dx.doi.org/10.1016/j.autcon.2013.09.001

Ginevičius, R.; Suhajda, K.; Petraškevičius, V.; Šimkūnaitè, J. 2013. Lithuanian experience of quantitative evaluation of socioeconomic systems position by multicriteria methods, Procedia - Social and Behavioral Sciences 110: 952-960. http://dx.doi.org/10.1016/j.sbspro.2013.12.941

Heras-Saizarbitoria, I.; Arana, G.; Cilleruelo, E. 2013. Adoption of ISO 9000 management standard in EU's transition economies: the case of the Baltic states, Journal of Business Economics and Management 14(3): 481-499. http://dx.doi.org/10.3846/16111699.2011.634923

Kaklauskas, A.; Zavadskas, E. K.; Raslanas, S.; Ginevicius, R.; Komka, A.; Malinauskas, P. 2006. Selection of low-e windows in retrofit of public buildings by applying multiple criteria method COPRAS: a Lithuanian case, Energy and Buildings 38(5): 454-462.

http://dx.doi.org/10.1016/j.enbuild.2005.08.005
Kalibatas, D.; Zavadskas, E. K.; Kalibatiene, D. 2011. The concept of the ideal indoor environment in multi-attribute assessment of dwelling-houses, Archives of Civil and Mechanical Engineering 11(1): 89-101. http://dx.doi.org/10.1016/S1644-9665(12)60176-9

Ko, C. H.; Li, S. C. 2014. Enhancing submittal review and construction inspection in public projects, Automation in Construction 44: 33-46. http://dx.doi.org/10.1016/j.autcon.2014.03.027

Kutut, V.; Zavadskas, E. K.; Lazauskas, M. 2013. Assessment of priority options for preservation of historic city centre buildings using MCDM (ARAS), Procedia Engineering 57: 657-661. http://dx.doi.org/10.1016/j.proeng.2013.04.083

Lietuvos Respublikos Seimas (LRS). 2000. Civil Code of the Republic of Lithuania, Valstybes žinios No. 74-2262.

Lietuvos Respublikos Seimas (LRS). 1996. Law on Construction, Valstybès žinios No. 32-788.

Lepkova, N.; Uselis, R. 2013. Development of a quality criteria system for facilities management services in Lithuania, Procedia Engineering 57: 697-706. http://dx.doi.org/10.1016/j.proeng.2013.04.088

McGibbney, L. J.; Kumar, B. 2013. An intelligent authoring model for subsidiary legislation and regulatory instrument drafting within construction and engineering industry, Automation in Construction 35: $121-130$. http://dx.doi.org/10.1016/j.autcon.2013.04.005

Medineckiene, M.; Zavadskas, E. K.; Björk, F.; Turskis, Z. 2015. Multi-criteria decision-making system for sustainable building assessment/certifycation, $A r$ chives of Civil and Mechanical Engineering 15(1): 11-18. http://dx.doi.org/10.1016/j.acme.2014.09.001

Mitkus, S.; Mitkus, T. 2014a. Application of constructs in commercial dispute resolution, in the $8^{\text {th }}$ International Scientific Conference "Business and Management 2014”, 15-16 May 2014, Vilnius, Lithuania, 109-117.

Mitkus, S.; Mitkus, T. 2014b. Causes of conflicts in a construction industry: a communicational approach, Procedia - Social and Behavioral Sciences 110: 777-786. http://dx.doi.org/10.1016/j.sbspro.2013.12.922

Monghasemi, S.; Nikoo, M. R.; Fasaee, M. A. K.; Adamowski, J. 2015. A novel multi criteria decision making model for optimizing time-cost-quality trade-off problems in construction projects, Expert Systems with Applications 42(6): 3089-3104. http://dx.doi.org/10.1016/j.eswa.2014.11.032

Ooi, J. T.; Le, T. T.; Lee, N. J. 2014. The impact of construction quality on house prices, Journal of Housing Economics 26: 126-138. http://dx.doi.org/10.1016/j.jhe.2014.10.001

Porwal, A.; Hewage, K. N. 2013. Building Information Modeling (BIM) partnering framework for public construction projects, Automation in Construction 31: 204-214.

http://dx.doi.org/10.1016/j.autcon.2012.12.004 
Regulation (EU) No. 305/2011 of the European Parliament and of the council of 9 March 2011 laying down harmonised conditions for the marketing of construction products and repealing Council Directive 89/106/EEC.

Staniūnas, M.; Medineckienė, M.; Zavadskas, E. K.; Kalibatas, D. 2013. To modernize or not: Ecological-economical assessment of multi-dwelling houses modernization, Archives of Civil and Mechanical Engineering 13(1): 88-98. http://dx.doi.org/10.1016/j.acme.2012.11.003

STR 1.01.05:2007. Technical Construction Regulation "Normative Technical Construction Documents", 2007.

STR 1.05.06:2010. Technical Construction Regulation "Design of a Construction Works", 2010.

STR 1.12.06:2002. Technical Construction Regulation "The Purpose and Life Span of Construction Works", 2002.

Succar, B.; Sher, W.; Williams, A. 2013. An integrated approach to BIM competency assessment, acquisition and application, Automation in Construction 35: $174-189$.

http://dx.doi.org/10.1016/j.autcon.2013.05.016

Supreme Court of Lithuania. 2010a. AB "Glasma LT" v. UAB "Senasis dvaras". Supreme Court of Lithuania, Case No. 3K-3-496/2010.

Supreme Court of Lithuania. 2014. AB firma "VITI" $v$. $U A B$ "KRS". Supreme Court of Lithuania, Case No. 3K-3-52/2014.

Supreme Court of Lithuania. 2005. BUAB “Atnava” $v$. Vilnius City Municipality Administration. Supreme Court of Lithuania, Case No. 3k-3-235.

Supreme Court of Lithuania. 2011a. UAB "Eurometras" v. National Land Service to the Ministry of Agriculture. Supreme Court of Lithuania, Case No. 3K-3-244/2011.

Supreme Court of Lithuania. 2010b. UAB "Jaukuriai" v. BUAB "Forsitia". Supreme Court of Lithuania, Case No. 3K-3-469/2010.

Supreme Court of Lithuania. 2012. UAB "KRS" v. TUUB "Energija", V.D. and J. K. Supreme Court of Lithuania, Case No. 3K-3-332/2012.

Supreme Court of Lithuania. 2010c. UAB "Melesta" v. $U A B$ "Mechanika". Supreme Court of Lithuania, Case No. 3K-3-489/2010.
Supreme Court of Lithuania. 2013. UAB "Minduvos statyba" v. A. P. and N. P. Supreme Court of Lithuania, Case No. 3K-3-679/2013.

Supreme Court of Lithuania. 2011b. UAB "Vaivorykštè" v. UAB “AR10”. 2011. Supreme Court of Lithuania, Case No. 3K-3-115/2011.

Tamošaitienè, J.; Zavadskas, E. K.; Turskis, Z. 2013. Multi-criteria risk assessment of a construction project, Procedia Computer Science 17: 129-133. http://dx.doi.org/10.1016/j.procs.2013.05.018

Taylor, T.; Counsell, J.; Gill, S. 2013. Energy efficiency is more than skin deep: improving construction quality control in new-build housing using thermography, Energy and Buildings 66: 222-231. http://dx.doi.org/10.1016/j.enbuild.2013.07.051

The Resolution No. 1316, October 21 $1^{\text {st }}$, 2004, of the Government of the Republic of Lithuania on the approval of the Distribution of Regulation Areas of Normative Documents of Building safety and Purpose Between Public Authorities. 2004. Official Gazette, No. 156-5701.

Wang, Y. R.; Kong, S. L. 2012. Applying genetic algorithms for construction quality auditor assignment in public construction projects, Automation in Construction 22: 459-467. http://dx.doi.org/10.1016/j.autcon.2011.11.005

Wu, Y.; Huang, Y.; Zhang, S.; Zhang, Y. 2012. Quality self-control and co-supervision mechanism of construction agent in public investment project in China, Habitat International 36(4): 471-480. http://dx.doi.org/10.1016/j.habitatint.2012.05.002

Zagorskas, J.; Zavadskas, E. K.; Turskis, Z.; Burinskienè, M.; Blumberga, A.; Blumberga, D. 2014. Thermal insulation alternatives of historic brick buildings in Baltic Sea Region, Energy and buildings 78: 35-42.

Zavadskas, E. K.; Antucheviciene, J.; Šaparauskas, J.; Turskis, Z. 2013. Multi-criteria assessment of facades' alternatives: peculiarities of ranking methodology, Procedia Engineering 57: 107-112. http://dx.doi.org/10.1016/j.proeng.2013.04.016

Zhong, B. T.; Ding, L. Y.; Luo, H. B.; Zhou, Y.; Hu, Y. Z.; Hu, H. M. 2012. Ontology-based semantic modeling of regulation constraint for automated construction quality compliance checking, Automation in Construction 28: 58-70. http://dx.doi.org/10.1016/j.autcon.2012.06.006 